\title{
Supply Reorder Point in Response to Lead-Time Uncertain Demand
}

\author{
Shahryar Sorooshian ${ }^{1, *}$ and Omid Jadidi ${ }^{2}$ \\ ${ }^{\prime}$ Department of Business Administration University of Gothenburg, Gothenburg, Sweden \\ ${ }^{2}$ Bill Munday School of Business, St Edward's University, Texas, United States
}

Received 11 May 2021; Accepted 24 June 2021

\begin{abstract}
The reorder point as a vital operational decisions in manufacturing is deliberated in this article. For that, a procedure to manage demand uncertainty during the lead-time is discussed on a seminar for university students; and is reviewed here on the basis of the classic economic order quantity. The procedure with consideration of forecasting information was less highlighted for practitioners, though it is very applied for manufacturing industries.
\end{abstract}

Keywords: Economic order quantity, Buffet stock, Dynamic demand, Reorder point, Inventory.

\section{Introduction.}

Ranjith and Pillai [1] state that stock plays a significant role in supply chains; it decreases each member's service level in a production chain and creates high inventory costs for the supply chain. They also argue that a buffer stock is to be retained by each participant to prevent stocking out. Besides, Sarkar et al. [2] believe that with today's highly oscillating demand for any products, management of buffer stocks and lead-times have become even more difficult than past. At the present time, according to Ranjith and Pillai [1], due to various market conditions, most businesses face unpredictable demand. In order to lessen the likelihood that the item will be out of stock, buffer stock is an extra volume of raw materials or input products kept in the warehouse [3]. It is a safety stock used in the event that sales are higher than forecasted demand for the lead-time period. Industries need procedures to determine the optimum extent for reorder point considering buffer stock and demand fluctuation as an advancement in inventory management principles for the EOQ (Economic Order Quantity) model. Some of the students of the University of Gothenburg had a guest speaker to provide a procedure to resolve the uncertain demand issue for buffer stock and reorder point decisions and this paper is being presented to review the outcome. The seminar speaker is also invited to review and edit the manuscript as the second author of the work.

\section{Procedure and Numerical Example.}

A numerical example was used to explain the calculation of the optimum level of reorder point. Figure 1 proposes a procedure for this decision-making aim and table 1 presents the demand for the past eight days of a manufacturing firm. Based on the information presented in the table, forecasting the demand for the next day based on the 3 periods moving average forecasting method, though any other forecasting method can be used as well. The forecasted demand for a day of those firms will be the average of the three last available

*E-mail address: sorooshian@gmail.com

ISSN: 1791-2377 @ 2021 School of Science, IHU. All rights reserved.

doi:10.25103/jestr.142.08 demands, 127 Items. Now, on the basis of this forecasted demand per day, we can forecast the demand for the next year assuming 350 working days per year. $127 \times 350(=44450)$ is the forecasted demand for a year. Economic order quantity (EOQ) on the basis of an assumption of the fixed $\$ 200$ for ordering costs per purchase order and $\$ 10$ for annual holding cost per unit Based on equation 1 for EOQ calculation, the economic order quantity is 1333.4 items.

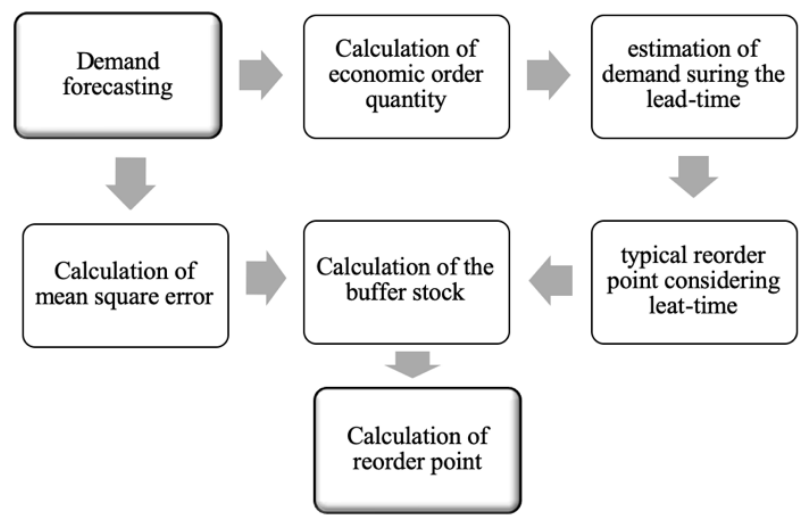

Fig. 1. Proposed proceedure

$\mathrm{EOQ}=(2 \times \text { Demand } \times \text { Order cost } / \text { Holding cost })^{1 / 2}$

Table 1. Available demand data from a firm

\begin{tabular}{c|c|c|c|c|c|c|c|c}
\hline Day & $\mathbf{1}$ & $\mathbf{2}$ & $\mathbf{3}$ & $\mathbf{4}$ & $\mathbf{5}$ & $\mathbf{6}$ & $\mathbf{7}$ & $\mathbf{8}$ \\
\hline $\begin{array}{c}\text { Actual } \\
\text { Demand } \\
\text { Forecasted } \\
\text { demand } \\
\text { (with 3 }\end{array}$ & 100 & 120 & 110 & 115 & 125 & 130 & 131 & 120 \\
$\begin{array}{c}\text { periods } \\
\text { moving } \\
\text { average) }\end{array}$ & - & - & - & 110 & 115 & 116.7 & 123.3 & 128.7 \\
\hline
\end{tabular}

For the sake of this example, let's assume the lead time for this item is 4 days. Hence, $4 \times 127(=508)$ is the typical reorder point and 508 items are the expected demand during the lead times. However, today's highly oscillating demand makes forecasting uncertain. If the actual demand exceeds the forecasted 508 items per any lead-time, customer satisfaction will be negatively affected. Buffer stock is necessary then, 
however, the extra stock should be avoided due to its costs. Calculation of the optimum buffer stock is the objective now. Equation 2 is to calculate the buffer stock. Where Z-score is determined corresponding to the desired service level from the standard normal table. The standard deviation lead-time period demand is expressed as $\sigma_{\text {DLT }}$.

\section{Buffer Stock $=\mathrm{Z} \times \sigma_{\mathrm{DLT}}$}

For the sake of this example, $\% 95$ is the target probability to meet demand during the lead time. Referring to the presented information in table 1 , the mean squared error (MSE) is calculated as 87.3; which is the golden key, variance. Thus, 9.3 is the standard deviation of demand per day. $\Sigma_{\mathrm{DLT}}=$ $9.3 \times(4)^{1 / 2}$. Next, the buffer stock will be calculated as $1.6 \times 9.3 \times(4)^{1 / 2}(=30.74)$.

The reorder point considering the buffer stock should be the typical reorder point plus the calculated buffer stock, or $508+30.74(=538.74)$ items.

\section{Conclusion.}

The procedure for calculation of the reorder point with consideration of buffer stock is presented in this paper for providing a better operations performance in response to uncertain demands. However, decision makers should consider When the service level is greater than $\% 50$ then $\mathrm{Z}$ score is positive making the re-order point larger than the expected demand during lead time (or the buffer stock $>0$ ). When the service level is smaller than $\% 50$ then $\mathrm{Z}$ is negative making the re-order point lesser than the expected demand during lead time (or the buffer stock $<0$ ). Although the procedure is practical, suggestion for future studies is to consider inventory shrinkage for a more accurate calculation of reorder points.

This is an Open Access article distributed under the terms of the Creative Commons Attribution License.

\section{References}

1. AM Ranjith, VM.Pillai, "Determination of Safety Stock in Divergent Supply Chains with Non-stationary Demand Process". In: Pandey P.M., Kumar P., Sharma V. (eds) Advances in Production and Industrial Engineering. Lecture Notes in Mechanical Engineering. $\quad$ Springer. https://doi.org/10.1007/978-981-15-5519-0_6.

2. S. Sarkar, .Giri, "Safety stock management in a supply chain model with waiting time and price discount dependent backlogging rate in stochastic environment". Oper Res Int J. 2020; https://doi.org/10.1007/s12351-020-00587-1.

3. JD. Wisner, KC.Tan, GK. Leong, "Principles of supply chain management: A balanced approach". 5th ed., Cengage Learning; 2019 